\title{
Effect of Irrigation Scheduling on Crop Growth Parameters of Babycorn under Drip Irrigation
}

\author{
K. Sai Manogna ${ }^{*}$, M. Srinivas Rao, M. Sai Ram, T. Durga Bhavani and A. Mani \\ College of Agricultural Engineering, Bapatla-522101, India \\ *Corresponding author
}

\section{A B S T R A C T}

\begin{tabular}{|l|}
\hline Ke y w o r d s \\
Baby corn, Irrigation \\
Scheduling, \\
Evapotranspiration, Plant \\
height, Water use \\
efficiency
\end{tabular}

\section{Introduction}

Land and water management are central to agriculture and rural development, and are intrinsically linked to challenges of food insecurity and poverty, climate change and adaptation and mitigation as well as degradation and depletion of natural resources.

Combination of high yielding varieties, enhanced availability of water and fertilizers, the three key inputs in agriculture, transformed India from a country of begging bowl to one with over-flowing granaries (Singh, 2013). With a food grain production touching an all-time record level of 263 plus million tonnes (Mt) in 2013-14, Indian agriculture has made stupendous progress in ensuring food security to its vast population.

Presently agriculture is the largest consumer of water $(82.8 \%)$ in the country. It is expected that reduction in size in land holding, decreasing per capita water availability, The availability of water for agricultural sector is bound to decrease due to fierce competition from industrial, power and domestic use in urban areas while the same time food production must be increased to meet the food grain requirement of the growing population will seriously affect the sustainable use of water resources and it will make it difficult to accomplish the largest production. Hence, to ensure sufficient availability of food, fodder, 
fiber and fuel for the present generation without leaving any stress for the requirement for future generation water use efficiency in agricultural production has to be essentially improved at field level.

Adaptation of drip irrigation and fertigation proved to be technically feasible and economically viable and helps in saving significant amount of water and increase the quality and quantity of produce. Drip irrigation offers a great potential to improve water management by improving cop yield and quality using less water and by localizing fertilizer and chemical applications to enhance their efficient use and to reduce pollution risk (Fischer et al., 2007). It can be also called as localized irrigation, to emphasize that only part of the soil volume is wetted (Lamm et al., 2007). Baby corn is a low-calorie vegetable. The demand for baby corn is rapidly increasing in urban areas in India. Baby corn is grown from miniature corn plants, but it is actually just regular corn that has been picked before its matured. Due to its short duration crop can be fitted in an intensive cropping system (Dass et al., 2008) baby corn has a nutritional makeup closer to a non-starchy vegetable. Plus, it is a good source of essential nutrients. Baby corn is a source of sodium. Baby corn is nutrient-rich, iron, and essential vitamins are vitamin A, vitamin C. Keeping this view a field experiment was conducted to compute crop water requirement of baby corn and to know the effect of irrigation scheduling on growth parameters of baby corn

\section{Materials and Methods}

The experiment was carried out at field irrigation laboratory with an area of $270 \mathrm{~m}^{2}(30 \mathrm{~m} \times 9 \mathrm{~m})$ CAE, Bapatla. It is geographically situated at $15^{\circ} 54^{\prime} 00^{\prime \prime} \mathrm{N}$ latitude and $80^{\circ} 28^{\prime} 0^{\prime \prime} \mathrm{E}$ longitude and at an altitude of $6 \mathrm{~m}$ above mean sea level. The irrigation water was collected from the well from which irrigation water was supplied to the crop through drip. The irrigation water quality was analyzed using standard methods $\mathrm{P}^{\mathrm{H}}, \mathrm{Ec}_{\mathrm{w}}$ were found to be 6.68 and 0.41 . SAR and RSC were 0.75 and $1.17 \mathrm{mel}^{-1}$. The experiment was laid out with two main treatments, three sub treatments and replicated three times. Different irrigation schedules were to arrive at optimal irrigation scheduling for enhancing water use efficiency. The irrigation interval proposed was daily and alternate day irrigation. The amount of irrigation application was planned at $1.0 \mathrm{ET}_{\mathrm{c}}$, $0.8 \mathrm{ET}_{\mathrm{c}}$ and $0.6 \mathrm{ET}_{\mathrm{c}}$.

Where,

$1.0 \mathrm{ET}_{\mathrm{c}}-100 \%$ Irrigation,

$0.8 \mathrm{ET}_{\mathrm{c}}-80 \%$ Irrigation

$0.6 \mathrm{ET}_{\mathrm{c}}-\mathrm{-} 60 \%$ Irrigation

Drip irrigation system was adopted for water supply. The dripper lines were laid at $1.2 \mathrm{~m}$ apart with an emitter spacing of $40 \mathrm{~cm}$ for discharge rates of $4 \mathrm{l} / \mathrm{hr}$. The end plugs (caps) were fixed to all main, sub main and laterals to facilitate maintenance of the system.

\section{Irrigation scheduling}

Irrigation was scheduled based on ETc. Reference crop evapotranspiration was estimated by using Penman Monteith method. $\mathrm{ET}_{\mathrm{o}}$ multiplied by crop coefficient gives crop evapotranspiration. The application rate and irrigation time were calculated by using the following formulae.

Application rate $\left(\mathrm{mm} \mathrm{hr}^{-1}\right)=\mathrm{Q} / \mathrm{S}_{1} \times \mathrm{S}_{\mathrm{e}}-(1)$

Irrigation time (in hours) $=\frac{\mathrm{ET}_{\mathrm{c}} \times \mathrm{W} . \mathrm{P} \times \mathrm{C} 60}{\text { Application rate }}$

Where $\mathrm{Q}=$ Emitter flow rate $\left(1 \mathrm{~h}^{-1}\right), \mathrm{S}_{1}=$ Spacing between laterals $\mathrm{S}_{\mathrm{e}}=$ Spacing 
between emitters $(\mathrm{m}), \quad \mathrm{ET}_{\mathrm{c}}=$ Crop evapotranspiration $(\mathrm{mm}), \quad \mathrm{WP}=$ Wetting percentage $(\%)$

\section{Results and Discussion}

The crop water requirement of baby corn was computed using CROP WAT software. The effect of irrigation scheduling on plant height, root zone length and width, number of baby corns per plot, yield. CROPWAT is a programme that uses FAO Penman-Monteith equation for calculating reference crop evapotranspiration. The reference evapotranspiration estimated for the crop duration is $356 \mathrm{~mm}$. The estimated crop evapotranspiration baby corn is $273.70 \mathrm{~mm}$ (Table 1).

The demand of water is more for the midseason stage $(104.47 \mathrm{~mm})$ during which the development of cob was initiated (Table 2).

Plant height of baby corn in daily irrigation and alternate day under different irrigation treatments

Plant growth in terms of growth rate, vigor and stand of crop provide an index of productivity of crop (Fig. 1). The plant height recorded with $1.0 \mathrm{ET}_{\mathrm{c}}$ of irrigation application was $2 \mathrm{~m}$. It is significantly higher than the rest of the treatments. The Lowest plant height $1.49 \mathrm{~m}$ was recorded with $0.6 \mathrm{ET}_{\mathrm{c}}$ of water application in alternate day water application with two day interval of irrigation frequency.

Root length and width of baby corn crop in daily and alternate irrigation under different irrigation treatments

It was found that the root length of baby corn was varied in different treatments of daily and alternate day irrigation. This is due to application of water with drip system and the root distribution pattern is mainly concentrated under and beside the laterals (Fig. 2).

\section{Number of baby corns recorded}

The $1.0 \mathrm{ET}_{\mathrm{c}}$ irrigation treatment has shown more no. of baby corns (461) in daily irrigation treatment. It was 194 for $1.5 \mathrm{ET}_{\mathrm{c}}$ which was lowest in alternate day irrigation. No. of baby corns in $1.0 \mathrm{ET}_{\mathrm{c}}$ of irrigation application was significantly higher than the other treatments was shown in figure 3.

Table.1 Crop evapotranspiration of babycorn in various growth stages

\begin{tabular}{|l|c|c|}
\hline S. No & Crop growth stages & Crop evapotranspiration ET $_{\mathrm{c}}(\mathbf{m m})$ \\
\hline $\mathbf{1}$ & Initial stage & 22.539 \\
\hline $\mathbf{2}$ & Development stage & 99.70 \\
\hline $\mathbf{3}$ & Mid season & 116.07 \\
\hline $\mathbf{4}$ & Late season & 35.40 \\
\hline $\mathbf{5}$ & Total & 273.70 \\
\hline
\end{tabular}

Table.2 Amount of water applied in various growth stages under different irrigation treatments

\begin{tabular}{|l|l|l|l|l|}
\hline S. No & Crop growth stages & $1 \mathbf{E T}_{\mathrm{c}}(\mathrm{mm})$ & $0.8 \mathrm{ET}_{\mathrm{c}}(\mathrm{mm})$ & $0.8 \mathrm{ET}_{\mathrm{c}}(\mathrm{mm})$ \\
\hline $\mathbf{1}$ & Initial stage & 20.28 & 16.22 & 12.16 \\
\hline $\mathbf{2}$ & Development stage & 89.73 & 71.78 & 53.83 \\
\hline $\mathbf{3}$ & Mid season & 104.47 & 83.57 & 62.68 \\
\hline $\mathbf{4}$ & Late season & 31.99 & 25.59 & 62.68 \\
\hline $\mathbf{5}$ & Total & 246.47 & 197.17 & 147.88 \\
\hline
\end{tabular}


Table.3 Correlation between different irrigation treatments and growth parameters of baby corn

\begin{tabular}{|l|l|l|l|l|l|l|l|}
\hline Parameters & $\begin{array}{l}\text { Amount } \\
\text { of water } \\
\text { applied }\end{array}$ & $\begin{array}{c}\text { Plant } \\
\text { height }\end{array}$ & $\begin{array}{c}\text { Root } \\
\text { length }\end{array}$ & $\begin{array}{c}\text { Root } \\
\text { width }\end{array}$ & $\begin{array}{c}\text { No. of } \\
\text { baby } \\
\text { corns }\end{array}$ & Yield & $\begin{array}{c}\text { Water } \\
\text { use } \\
\text { efficiency }\end{array}$ \\
\hline $\begin{array}{l}\text { Amount of } \\
\text { water applied }\end{array}$ & 1 & & & & & & \\
\hline Plant height & 0.854813 & 1 & & & & & \\
\hline Root length & 0.95367 & 0.886319 & 1 & & & & \\
\hline Root width & 0.214585 & 0.592926 & 0.300679 & 1 & & & \\
\hline $\begin{array}{l}\text { No. of baby } \\
\text { corns }\end{array}$ & 0.644874 & 0.762343 & 0.73681 & 0.749769 & 1 & & \\
\hline $\begin{array}{l}\text { Water use }- \\
\text { efficiency }\end{array}$ & 0.129334 & 0.397996 & 0.25861 & 0.885358 & 0.830188 & 0.816723 & 1 \\
\hline
\end{tabular}

Table.4 Interactions between irrigation levels and growth parameters of baby corn

\begin{tabular}{|c|c|c|c|c|c|c|c|}
\hline \multirow{2}{*}{\multicolumn{2}{|c|}{$\begin{array}{l}\text { Irrigation } \\
\text { treatments }\end{array}$}} & \multicolumn{6}{|c|}{ Plant growth parameters } \\
\hline & & \multirow{2}{*}{$\begin{array}{c}\begin{array}{c}\text { Plant } \\
\text { height }\end{array} \\
2\end{array}$} & \multirow{2}{*}{$\begin{array}{c}\begin{array}{c}\text { Root } \\
\text { length }\end{array} \\
14.9\end{array}$} & \multirow{2}{*}{$\begin{array}{c}\begin{array}{c}\text { Root } \\
\text { width }\end{array} \\
8\end{array}$} & \multirow{2}{*}{$\begin{array}{c}\begin{array}{c}\text { No. of } \\
\text { Baby } \\
\text { corns }\end{array} \\
461 \\
\end{array}$} & \multirow{2}{*}{$\begin{array}{l}\text { Yield } \\
5.29\end{array}$} & \multirow{2}{*}{$\begin{array}{c}\text { Water use } \\
\text { efficiency }\end{array}$} \\
\hline Daily & $1.0 \mathrm{ET}_{\mathrm{c}}$ & & & & & & \\
\hline & $0.8 \mathrm{ET}_{\mathrm{c}}$ & 1.8 & 12.2 & 10 & 449 & 5.45 & 27.6 \\
\hline & $0.6 \mathrm{ET}_{\mathrm{c}}$ & 1.5 & 11.2 & 6.9 & 382 & 3.6 & 24.3 \\
\hline \multirow[t]{3}{*}{ Alternate } & $1.0 \mathrm{ET}_{\mathrm{c}}$ & 1.73 & 14 & 5.8 & 401 & 4.3 & 17.44 \\
\hline & $0.8 \mathrm{ET}_{\mathrm{c}}$ & 1.65 & 11.8 & 5.5 & 319 & 2.9 & 14.5 \\
\hline & $0.6 \mathrm{ET}_{\mathrm{c}}$ & 1.49 & 10.45 & 5.23 & 194 & 1.62 & 10.95 \\
\hline \multicolumn{2}{|l|}{ Mean } & 1.695 & 12.425 & 6.921667 & 367.6667 & 3.76 & 19.39833 \\
\hline \multicolumn{2}{|c|}{ Standard error } & 0.079025 & 0.693992 & 0.752907 & 40.48511 & 0.62 & 2.533667 \\
\hline \multicolumn{2}{|c|}{ Confidence level } & 0.203141 & 1.783963 & 1.93541 & 104.0703 & 1.58 & 6.512999 \\
\hline
\end{tabular}

Fig.1 Height of plant in daily irrigation (left side) and alternate day irrigation (right side)
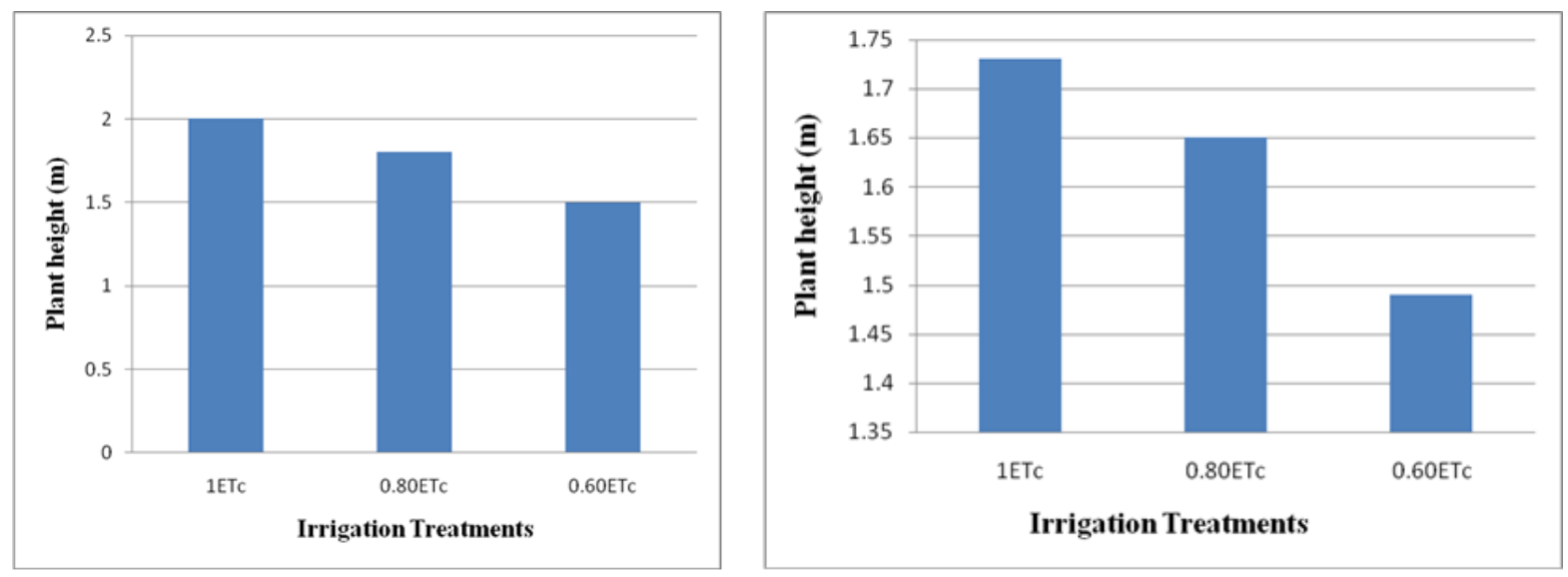
Fig.2 Root length and width in daily and alternate day irrigation treatments
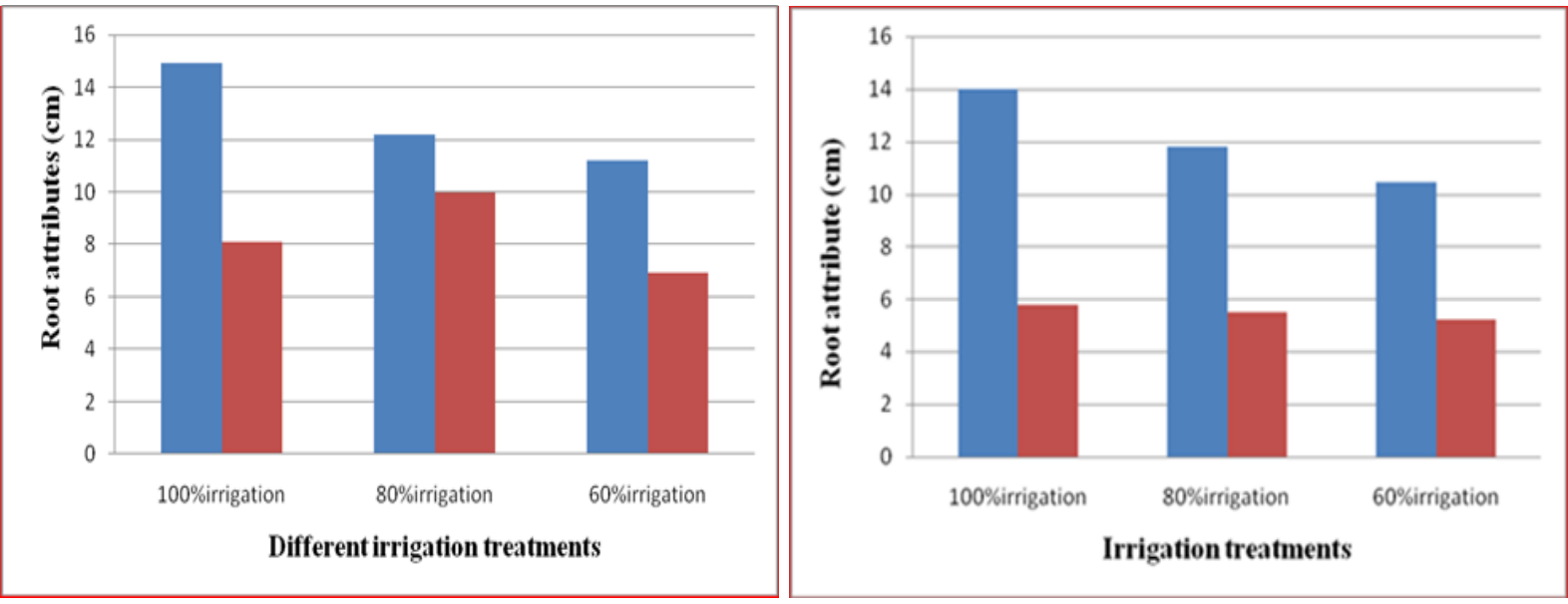

Fig.3 Total no. of babycorns in daily and alternate day irrigation
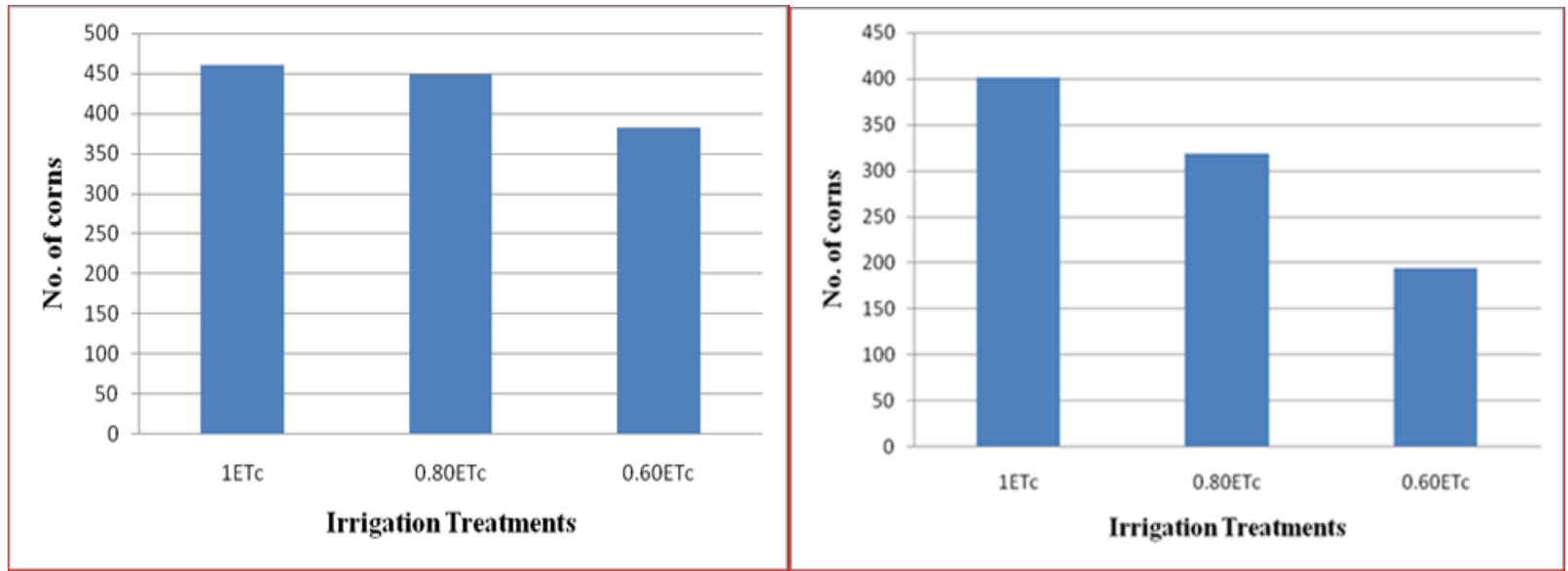

Fig.4 Weight of cobs with and without husk in daily irrigation
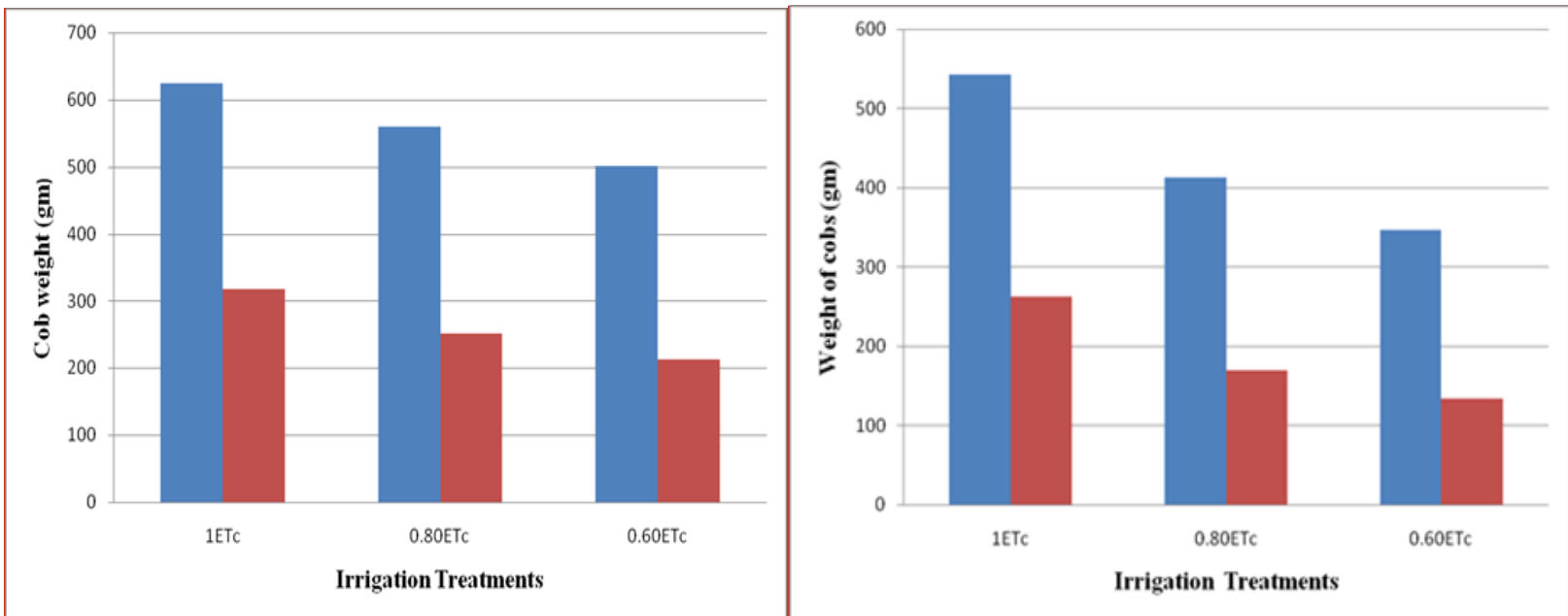
Weight of cobs with and without husk in daily irrigation and alternate day irrigation

Ten cobs ten of same size and quality were taken from the all irrigation treatments were taken from the each plot. 1.0 $\mathrm{ET}_{\mathrm{c}}$ treatment recorded highest cob weight (625 gms), followed by $0.80 \mathrm{ET}_{\mathrm{c}}(560 \mathrm{gms})$.In alternate day irrigation weight of 543 gms was recorded. Both treatments lowest weight was observed in $0.6 \mathrm{ET}_{\mathrm{c}}$ Because of full application of water, the cobs were developed fully in1.0 $\mathrm{ET}_{\mathrm{c}}$ treatment (Fig. 4).

Correlation between different irrigation treatments and growth parameters of baby corn

The relationship between different irrigation treatments and growth parameters of baby corn was worked out at 5\% level of significance for 18 samples $(r=0.5)$, through correlation analysis of the data (Table 3 ). The correlation coefficient of 0.5 or more is significant.

The plant height $(\mathrm{r}=0.854)$ is significantly influenced by amount of water applied. Similarly root length(r=0.953), no. of baby corns per treatment $(\mathrm{r}=0.64)$, yield $(0.66)$, are significantly influenced by amount of water applied.

Root length $(\mathrm{r}=0.88)$, root width $(\mathrm{r}=0.59)$, no. of corns (0.76), yield $(r=0.8)$ are associated and correlated with plant height.

No. of baby corns $(r=0.736)$, yield $(r=0.738)$ is significantly associated with root length. Root width is significantly correlated with the no. of baby corns $(\mathrm{r}=0.749)$, yield $(\mathrm{r}=0.83)$ and WUE (0.88). No. of baby corns per treatment) is significantly associated with Yield ( $\mathrm{r}=0.97)$ and Water use efficiency $(\mathrm{r}=0.83)$. Yield is significantly affected the WUE $(\mathrm{r}=0.81)$ is shown in table 3 .
Interactions between different irrigation treatments and growth parameters of Baby corn

The mean interaction effect between irrigation levels and crop growth parameters was statistically analyzed (Table 4). The interaction effect showed significantly higher cob yield with application of irrigation at 0.8 $\mathrm{ET}_{\mathrm{c}}$. The plant height is significant in daily $1.0 \mathrm{ET}_{\mathrm{c}}, 0.8 \mathrm{ET}_{\mathrm{c}}$ and alternate $1.0 \mathrm{ET}_{\mathrm{c}}$. Root length is significant in daily $1_{\mathrm{ET}}$ irrigation treatment and alternate day $1 \mathrm{ET}_{\mathrm{c}}$. Root width is significant in daily $0.8 \mathrm{ET}_{\mathrm{c}}$ and $1 \mathrm{ET}_{\mathrm{c}}$ irrigation treatments. No. of baby corns per treatment is significant in all irrigation treatments expect $0.6 \quad \mathrm{ET}_{\mathrm{c}}$ alternate day irrigation.

The plant height is significant in daily 1.0 $\mathrm{ET}_{\mathrm{c}}, 0.8 \mathrm{ET}_{\mathrm{c}}$ and alternate $1 \mathrm{ET}_{\mathrm{c}}$. Root length is significant in daily $1 \mathrm{ET}_{\mathrm{c}}$ irrigation treatment and alternate day $1 \mathrm{ET}_{\mathrm{c}}$. Root width is significant in daily $0.8 \mathrm{ET}_{\mathrm{c}}$ and $1_{\mathrm{ET}}$ irrigation treatments.

In this study higher values of growth parameters like plant height, root length, root width, No. of baby corns with husk and without husk were observed in daily irrigation treatment of $1.0 \mathrm{ET}_{\mathrm{c}}$. The difference in no. of baby corns with husk in $1.0 \mathrm{ET}_{\mathrm{c}}$. daily and 0 . $\mathrm{ET}_{\text {c. }}$ irrigation was 65 All parameters were observed lowest in $0.6 \quad \mathrm{ET}_{\mathrm{c}}$ irrigation treatment due to inadequate application of water in alternate days which lead to water stress. Based on the results, it can be suggest that $0.8 \mathrm{ET}_{\mathrm{c}}$ daily irrigation approach could be a good strategy to improve water productivity when full irrigation is not possible.

\section{References}

Abdul, S. M and Mazrooei, S. A. L. 2006. Crop water requirements of maize in the entisols of Kuwait. Tenth international 
water technology conference. IWTC10, Alexandria, Egypt. 781-795.

Adhikary. S, Koundinya, V.V., Pandit, M. K. and Bhattacharya, B. 2015. Evaluation of efficiency of Baby corn based vegetable intercropping systems. International journal of plant \& Soil science. 5(6): 366-374.

Dass, S., Yadav, V.K., Jat, M.L., Kaul, J., Singh, I., Rakshit, S., Singh, K.P., Sekhar, J.C and singh, R.P. 2008. Single cross hybrid seed production in maize. Directorate of mazie Research, Tech Bul. DMR, 1:11.

Dastane, N.G. 1972. A practical manual for water use research in Agriculture. Navabharat Prakashan, Pune.
Fischer, G., Tubileo, F.N., Velthuizen, V.H., and Wiberg, D. 2007. Climate change impacts on irrigation water requirements: Effects of mitigation, 1990-2080. Tech. Forecasting Soc. Ch., 74:1083-1107.

Lamm, F.R., Ayars, J.E., Nakayama, F.S. 2007. Micro irrigation for crop production - Design, operation and Management. Elsevier Publications. 608p.

Mukesh, K and Rajput, T. B. S. 2014. Effect of drip irrigation and fertilizer application on yield of baby corn. Current Horticulture. 2(1): 34-38.

\section{How to cite this article:}

Sai Manogna, K., M. Srinivas Rao, M. Sai Ram, T. Durga Bhavani and Mani, A. 2018. Effect of Irrigation Scheduling on Crop Growth Parameters of Babycorn under Drip Irrigation. Int.J.Curr.Microbiol.App.Sci. 7(04): 407-413. doi: https://doi.org/10.20546/ijcmas.2018.704.046 